\title{
Evolution of surface of Pd-Rh bimetallic nanocubes and its correlation with $\mathrm{CO}$ oxidation
}

\author{
Wei Zhu ${ }^{1,2}$, Junjun Shan ${ }^{2}$, Luan Nguyen ${ }^{2}$, Shiran Zhang ${ }^{2}$, Franklin Feng Tao ${ }^{2^{*}}$ and Ya-Wen Zhang ${ }^{1^{*}}$
}

\begin{abstract}
Typically, varying pretreatment conditions probably results in the different catalytic performances for the bimetallic catalysts, and this originates from the surface evolution of catalysts during catalytic process. Hence, it is crucial to correlate surface chemistry (e.g., composition, chemical valence, etc.) of bimetallic nanocatalysts with their corresponding performances upon different pretreatments for the fundamental understanding of catalysis. Herein, compositionvaried (100) facet terminated Pd-Rh nanocubes (NCs) with the similar shape and sizes were prepared by a facile one-pot hydrothermal method to exclude the possible size and shape effect. Surface composition and valence state of these $\mathbf{P d}_{0.8}$ $\mathbf{R h}_{0.2}, \mathbf{P d}_{0.6} \mathbf{R h}_{0.4}$, and $\mathbf{P d}_{0.2} \mathbf{R h}_{0.8}$ NCs were tracked under different reaction conditions and during catalysis using a homebuilt ambient pressure $\mathrm{X}$-ray photoelectron spectrometer (APXPS). The correlation of active surface of Pd-Rh NCs and their corresponding catalytic performance was established.
\end{abstract}

Keywords: controllable synthesis, bimetallic nanocubes, ambient-pressure XPS, CO oxidation, surface chemistry

\section{INTRODUCTION}

An industrial catalyst typically consists of nanoparticles (NPs) with diverse morphologies, sizes, compositions, and interfaces. Its catalytic performance is the integrated contribution of these interplayed structural and compositional factors $[1,2]$. Hence, fundamental understanding of how a structural or compositional factor tunes catalytic performance, cannot be simply accomplished by using structure-undefined industrial catalysts as model catalysts [3-6].

It has been demonstrated that size [7-9] and shape [5,10-15] have significant influences on the catalytic performance of metal catalysts, while the fine manipula- tion of the two factors has been achieved by tuning kinetics of the crystal growth of colloidal NPs. Hence, controllable synthesis provides an ideal platform for the catalytic study of well-defined nanocatalysts, and bridges surface science investigations with industrially catalytic applications. Nevertheless, controllable synthesis of nanocrystals $[6,7,16,17]$ can readily tune overall composition of a single particle, but the surface composition of assynthesized bimetallic NPs usually appears to be very different from the overall composition. It is because that a variety of factors (e.g., surface capping agent, surrounding environment, surface energy, etc.) will probably change the surface composition during synthesis or storage $[18,19]$. And it has been demonstrated that surface reconstruction or segregation will take place by altering the reaction atmospheres [20]. So we still know little about the surface chemistry of these well-defined nanocrystals, particularly during the catalytic reaction.

What's more, pretreatments of catalysts, i.e., activation procedures which usually are conducted before the catalytic evaluations, can significantly influence their overall performances [21-24]. Hence, an "appropriate" activation method will lead to an optimal property of a catalyst. Variation of surface chemistry (e.g., composition, chemical valence, crystalline phase, etc.) is one of the key reasons for the elevated activity in light of the prior mechanism research [20,25-28]. In many cases, bimetallic site and metal/oxide interface generated from the commercial bimetallic or oxide-supported metallic catalysts will essentially determine the reaction energy barriers, and lead to diverse catalytic performances, such as $\mathrm{Cu}$ / $\mathrm{ZnO} / \mathrm{Al}_{2} \mathrm{O}_{3}$ for $\mathrm{CO}_{2}$ hydrogenation [29-31]. Therefore, to correlate the surface chemistry of model catalysts with their catalytic performance after various pretreatments

\footnotetext{
${ }^{1}$ Beijing National Laboratory for Molecular Sciences, State Key Laboratory of Rare Earth Materials Chemistry and Applications, PKU-HKU Joint Laboratory in Rare Earth Materials and Bioinorganic Chemistry, College of Chemistry and Molecular Engineering, Peking University, Beijing 100871, China

${ }^{2}$ Department of Chemical and Petroleum Engineering and Department of Chemistry, University of Kansas, Lawrence, KS 66045, USA

* Corresponding authors (emails: franklin.feng.tao@ku.edu (Tao F); ywzhang@pku.edu.cn (Zhang YW))
} 
with the aid of controllable syntheses and operando techniques will provide us a rational image to understand the evolution of surface chemistry of nanocatalysts during realistic catalytic reactions.

In this work, bimetallic $\mathrm{Pd}_{x} \mathrm{Rh}_{1-x} \mathrm{NPs}$ are chosen as the probe catalysts due to the high sensitivity of $\mathrm{Pd}$ and $\mathrm{Rh}$ to the reductive and oxidative atmospheres. Since the surface composition may change during the reaction according to the previous reports [20], exposed facet and size are kept the same via a wet chemistry synthetic method to exclude the probable structural effects. Herein, three sub-10 nm (100)-terminated $\mathrm{Pd}-\mathrm{Rh}$ nanocubes (NCs) (i.e., $\mathrm{Pd}_{0.8} \mathrm{Rh}_{0.2}, \mathrm{Pd}_{0.6} \mathrm{Rh}_{0.4}$, and $\mathrm{Pd}_{0.2} \mathrm{Rh}_{0.8}$ ) with different compositions but the same shape and size were synthesized via a facile hydrothermal method. CO oxidation was taken as the benchmark reaction. Activation barriers of $\mathrm{CO}$ oxidation on these as-synthesized and treated catalysts under different pretreatments were measured under kinetically controlled regime. These activation barriers were used as a descriptor of the catalytic performance of the real surface observed during catalysis. Surface composition and oxidation state of bimetallic NCs during pretreatments and catalysis were tracked with AP-XPS. Correlations between the surface chemistry of these catalysts and their catalytic performances upon different pretreatments were finally established.

\section{EXPERIMENTAL SECTION}

\section{Chemicals}

$\mathrm{RhCl}_{3} \cdot \mathrm{xH}_{2} \mathrm{O}$ ( $\geq 98 \%$; Sigma-Aldrich), $\mathrm{PdCl}_{2} \quad(\geq 99.9 \%$; Sigma-Aldrich), $\mathrm{NaCl}$ ( $\geq 99 \%$; Sigma-Aldrich), $\mathrm{Na}_{2} \mathrm{PdCl}_{4}$ (It was prepared by mixing 2 eqv. $\mathrm{NaCl}$ and 1 eqv. $\mathrm{PdCl}_{2}$ in water, and stirring overnight.), $\mathrm{HCl}$ (AR; Xilong Chemical Co., Ltd., China), $\mathrm{KBr}$ (99.999\%; Strem Chemicals, Inc.), poly(vinylpyrrolidone) (PVP; $M_{\mathrm{w}}: \sim 29,000$; Sigma-Aldrich), acetone ( $\geq 99.5 \%$; Alfa Aesar), ethanol (96\%; Alfa Aesar) and deionized water (Millipore, $18.2 \mathrm{M} \Omega \mathrm{cm}$ ) were used during the experiments.

\section{Synthesis of $\mathbf{P d}_{x} \mathbf{R h}_{1-x} \mathrm{NPs}$}

In a typical synthesis of $\mathrm{Pd}_{0.6} \mathrm{Rh}_{0.4} \mathrm{NCs}, 6.0 \mathrm{mmol}$ of $\mathrm{KBr}$ and $100 \mathrm{mg}$ of PVP were added to a $25-\mathrm{mL}$ Teflon-lined stainless steel autoclave and dissolved in $5 \mathrm{~mL}$ of deionized water. Then, $0.030 \mathrm{mmol}$ of $0.116 \mathrm{~mol} \mathrm{~L}^{-1} \mathrm{Na}_{2} \mathrm{PdCl}_{4}$ and $0.030 \mathrm{mmol}$ of $0.0956 \mathrm{~mol} \mathrm{~L}^{-1} \mathrm{RhCl}_{3}$ aqueous solution were added with stirring. The solution was diluted to $15 \mathrm{~mL}$ by deionized water. After that, the autoclave was sealed and kept at $180^{\circ} \mathrm{C}$ for $2 \mathrm{~h}$. After it cooled down to room temperature, the solution was centrifuged at the rate of $8,000 \mathrm{rpm}$ for $5 \mathrm{~min}$ at room temperature after introducing $40 \mathrm{~mL}$ of acetone. The black precipitates were washed with the mixture of water/acetone $(1: 4, v / v)$. The as-obtained NPs were dispersed well in water and ethanol. As illustrated in Fig. S1b, energy dispersive X-ray spectroscopy (EDS) analysis showed PdRh NCs were composed of $58.5 \% \mathrm{Pd}$ and $41.5 \% \mathrm{Rh}$ in atomic percentage (abbreviated as $\mathrm{Pd}_{0.6} \mathrm{Rh}_{0.4} \mathrm{NCs}$ ).

The synthesis of Pd NCs, $\mathrm{Pd}_{0.8} \mathrm{Rh}_{0.2} \mathrm{NCs}, \mathrm{Pd}_{0.2} \mathrm{Rh}_{0.8} \mathrm{NCs}$ and $\mathrm{Rh} \mathrm{NCs}$, and the post-treatment procedures were similar to the synthesis of $\mathrm{Pd}_{0.6} \mathrm{Rh}_{0.4} \mathrm{NCs}$, only with the changes on the addition amount of reactants (see Table 1 for detailed feed ratios of the reactants).

\section{Preparation of $\mathrm{SiO}_{2}$ supported Pd-Rh NCs catalysts} $200 \mathrm{mg}$ of $\mathrm{SiO}_{2}$ powder (200-300 nm; Sigma Aldrich) was dispersed in $10 \mathrm{~mL}$ of Pd-Rh NCs aqueous solution. Then the suspension was processed under ultrasonic for $4 \mathrm{~h}$. After centrifugation of the above suspension, the black precipitate was dried at $70^{\circ} \mathrm{C}$ overnight. As illustrated by the transmission electron microscopy (TEM) image (Fig. S2), Pd-Rh NCs were uniformly dispersed on the support without significant changes in morphology and size.

\section{Structural characterization}

TEM, high-resolution TEM (HRTEM), and EDS were conducted on an FEI TITAN 80-300 TEM operated at $300 \mathrm{kV}$ with an Oxford EDS attachment. The samples for TEM characterizations were prepared by dropping the

Table 1 Feed ratios of the reactants for synthesis of $\mathrm{Pd}_{x} \mathrm{Rh}_{1-x} \operatorname{NPs}(x=0,0.2,0.4,0.8,1.0)$

\begin{tabular}{cccccc}
\hline Sample & $\mathrm{Na}_{2} \mathrm{PdCl}_{4}(\mathrm{mmol})$ & $\mathrm{RhCl}_{3}(\mathrm{mmol})$ & $\mathrm{KBr}(\mathrm{mmol})$ & $\mathrm{PVP}(\mathrm{mg})$ & Composition analysis by EDS \\
\hline $\mathrm{Pd} \mathrm{NCs}$ & 0.12 & & 6.0 & 200 & $\mathrm{Pd} 83.9 \%, \mathrm{Rh} 16.1 \%$ \\
$\mathrm{Pd}_{0.8} \mathrm{Rh}_{0.2} \mathrm{NCs}$ & 0.096 & 0.024 & 6.0 & 200 & $\mathrm{Pd} 58.5 \%, \mathrm{Rh} 41.5 \%$ \\
$\mathrm{Pd}_{0.6} \mathrm{Rh}_{0.4} \mathrm{NCs}$ & 0.030 & 0.030 & 6.0 & 100 & $\mathrm{Pd} 17.3 \%, \mathrm{Rh} 82.7 \%$ \\
$\mathrm{Pd}_{0.2} \mathrm{Rh}_{0.8} \mathrm{NCs}$ & 0.024 & 0.096 & 12.0 & 200 & 75 \\
$\mathrm{Rh} \mathrm{NCs}$ & & 0.12 & 6.0 & & \\
\hline
\end{tabular}


colloid solution on copper grids coated with amorphous carbon and drying. Powder X-ray diffraction (PXRD) analyses were performed on a Rigaku D/MAX-2000 diffractometer (Japan) with $\mathrm{Cu} \mathrm{Kal}$ line $(\lambda=1.54 \AA)$ as the $\mathrm{X}$-ray source. Inductively coupled plasma atomic emission spectroscopy (ICP-AES) analyses were conducted on a Profile Spec ICP-AES spectrometer (Leeman, USA).

\section{Measurements of catalytic performance}

The catalytic performance of Pd-Rh bimetallic NCs for $\mathrm{CO}$ oxidation was measured in a fixed-bed flow reactor at atmospheric pressure. The gas composition of the mixture of reactants was $8 \% \mathrm{CO}, 20 \% \mathrm{O}_{2}$, and $72 \% \mathrm{Ar}$. The flow rate of the mixture was typically $100 \mathrm{~mL} \mathrm{~min}^{-1}$. In the case for pretreatments with $\mathrm{H}_{2}$ or $\mathrm{O}_{2}$, the catalysts were treated in-situ under a flow of $\mathrm{H}_{2}(5 \%$ in argon) or $\mathrm{O}_{2}$ (5\% in argon) with a flow rate at $50 \mathrm{~mL} \mathrm{~min}^{-1}$ at a certain temperature for $60 \mathrm{~min}$. There were two types of pretreatment methods applied in the study: one was successively treated with $\mathrm{H}_{2}\left(5 \%\right.$ in argon) and $\mathrm{O}_{2}(5 \%$ in argon) before the reaction (abbreviated as $\mathrm{H}_{2}-\mathrm{O}_{2}$ ); the other was only treated with $\mathrm{H}_{2}$ (5\% in argon) before the reaction, and then was treated with only $\mathrm{O}_{2}$ (5\% in argon) before the $2^{\text {nd }}$ cycle of reaction (abbreviated as $\mathrm{H}_{2}-$ reaction- $\mathrm{O}_{2}$ ). In the following text, we used the symbol "-" between different atmosphere treatments to represent the successive operation. The activation energy was measured in kinetically controlled range at which the conversion of CO was below $15 \%$. The catalytic evaluations were conducted in the temperature interval from $25-250^{\circ} \mathrm{C}$ to obtain the apparent activation energies.

As shown in Fig. S2, before being loaded into the catalytic reactor for catalytic measurements, the Pd-Rh bimetallic NCs were deposited on silica, in order to prevent the NCs from aggregating during the reactions. Typically, $5 \mathrm{mg}$ of $\mathrm{Pd}-\mathrm{Rh} / \mathrm{SiO}_{2}$ catalysts were used for kinetics study. The reliability of the fix-bed reactor was checked through a blank experiment with the same experimental parameters including reactant gases, flow rate, and reaction temperature. In the blank experiment, only silica supporting material was loaded. The blank experimental tests confirmed that there was no $\mathrm{CO}_{2}$ formed from reactor, gas lines, or other part in the temperature range of $25-$ $250^{\circ} \mathrm{C}$.

\section{In-situ/operando characterization}

The in-situ characterization of surface chemistry of Pd-Rh bimetallic catalysts during catalysis was performed with AP-XPS [32-39]. Monochromated $\mathrm{Al} \mathrm{Ka}$ line is used as $\mathrm{X}$-ray source. Unlike traditional under ultrahigh-vacuum
(UHV) studies, reactant gases are introduced to the reaction cell of AP-XPS and the gas flows through the catalyst surface at a desired temperature while data is collected with AP-XPS. The reaction cell is incorporated into the UHV chamber of AP-XPS system. Gas flows through the cell and exits through the exit port and an aperture that interfaces the gaseous environment in the reaction cell and vacuum environment of the pre-lens. Flow rate in the reaction cell is measured through a mass flow meter installed between each gas source and the entrance of the reaction cell. In this study, the typical flow rate of pure gas is in the range of $1-4 \mathrm{~mL} \mathrm{~min}^{-1}$. It approximately equals to the flow rate of $10-40 \mathrm{~mL} \mathrm{~min}^{-1}$ of gas with $10 \%$ reactants in catalytic measurement of a fixed-bed flow reactor. The total pressure of the mixture gas in the entrance is measured with a capacitance gauge, while the pressure at the exit is measured with another capacitance gauge. An average of the pressures at entrance and exit is defined to be the pressure above the catalyst in the reaction cell. More detailed description of the AP-XPS system can be found in the previous publications [32-39].

\section{Thermal stability tests}

Thermal stability tests under different atmospheres were performed on all the five $\mathrm{SiO}_{2}$-supported NCs samples. All the experiments were conducted in the atmosphereprotected tube furnace. To simulate the pretreatment conditions, the samples were respectively treated by $5 \%$ $\mathrm{O}_{2} / \mathrm{Ar}, 5 \% \mathrm{H}_{2} / \mathrm{Ar}$, and $5 \% \mathrm{H}_{2} / \mathrm{Ar}-5 \% \mathrm{O}_{2} / \mathrm{Ar}$ atmospheres at $280^{\circ} \mathrm{C}$ for $1 \mathrm{~h}$ with the heating rate of $2^{\circ} \mathrm{C} \mathrm{min}^{-1}$. TEM was applied to confirm the shape evolution and aggregation of the samples after the thermal treatments.

\section{RESULTS}

\section{Shape-controlled syntheses of Pd-Rh NCs}

As illustrated in the TEM images (Fig. 1a-e), monodisperse Pd-Rh NCs were synthesized in a high selectivity $(\geq 90 \%)$ via a facile hydrothermal method by the fine adjustment of synthetic parameters. The average sizes of $\mathrm{Pd}_{0.8} \mathrm{Rh}_{0.2} \mathrm{NCs}, \mathrm{Pd}_{0.6} \mathrm{Rh}_{0.4} \mathrm{NCs}$, and $\mathrm{Pd}_{0.2} \mathrm{Rh}_{0.8}$ NCs were $9.4 \pm 1.1 \mathrm{~nm}, 8.9 \pm 1.1 \mathrm{~nm}$, and $6.7 \pm 0.8 \mathrm{~nm}$, respectively (more than 100 particles were counted for each sample). In addition, pure Pd NCs and Rh NCs were synthesized as shown in Fig. 1. HRTEM image of $\mathrm{Pd}_{0.6} \mathrm{Rh}_{0.4}$ NCs (Fig. 1f) confirmed that the morphology of $\mathrm{Pd}_{0.6} \mathrm{Rh}_{0.4} \mathrm{NCs}$ was a typical cube enclosed by six (100) facets. Both HRTEM image and PXRD pattern (Fig. S3) confirmed that the assynthesized $\mathrm{Pd}-\mathrm{Rh} \mathrm{NCs}$ were in an fcc structure. As 


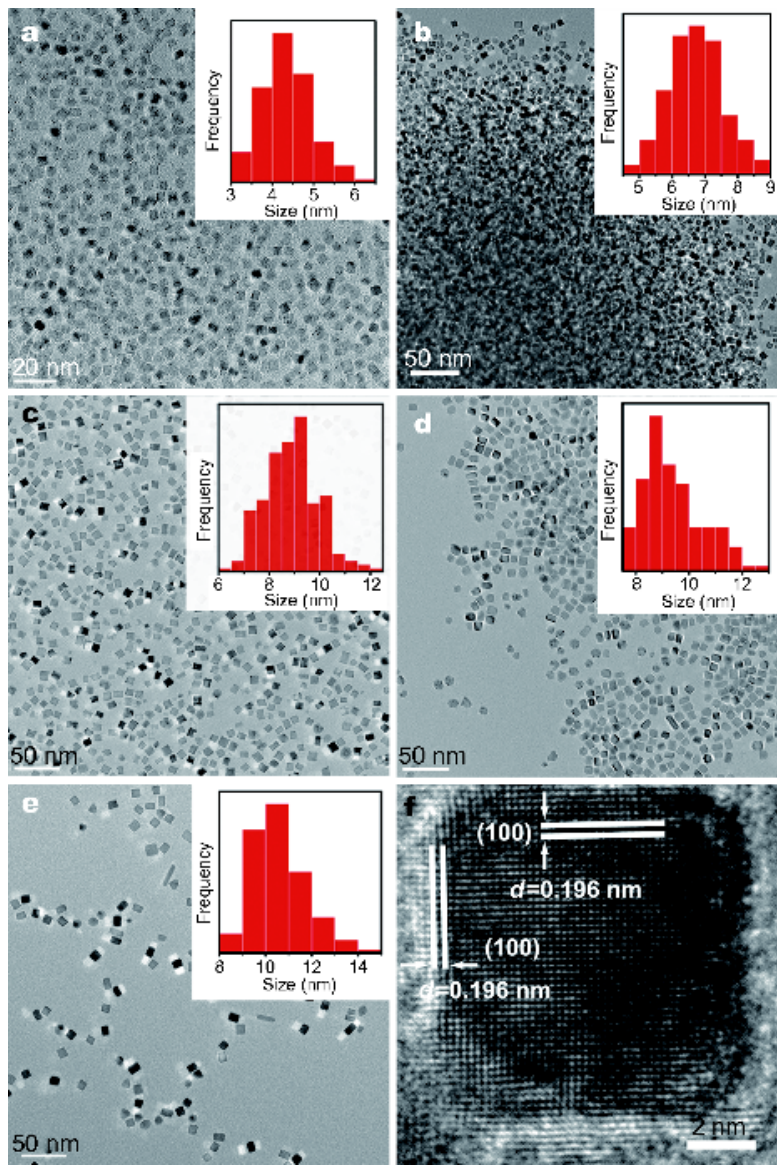

Figure 1 TEM images of the synthesized Rh NCs (a), $\mathrm{Pd}_{0.2} \mathrm{Rh}_{0.8} \mathrm{NCs}(\mathrm{b})$, $\mathrm{Pd}_{0.6} \mathrm{Rh}_{0.4} \mathrm{NCs}(\mathrm{c}), \mathrm{Pd}_{0.8} \mathrm{Rh}_{0.2} \mathrm{NCs}(\mathrm{d})$, and Pd NCs (e). The insets were the corresponding size distribution histograms. HRTEM image of the $\mathrm{Pd}_{0.6} \mathrm{Rh}_{0.4}$ NCs (f).

shown in Fig. S3, the peaks of $\mathrm{Pd}_{x} \mathrm{Rh}_{1-x}$ NCs XRD patterns shifted to low angles with the increase of Pd concentration, indicating a lattice expansion due to the incorporation of $\mathrm{Pd}$ into $\mathrm{Rh}$. The detail shape-control synthesis mechanism of Pd-Rh NCs by halide ions has been discussed in our previous reports [40-42].

\section{Thermal stability of Pd-Rh bimetallic NCs under different atmosphere treatments}

To confirm the possible aggregation or shape evolution of the monodispersed NCs after the thermal treatments of various atmospheres, TEM was utilized to check the $\mathrm{SiO}_{2}{ }^{-}$ supported samples after the thermal treatments. As shown in Fig. S2, all the samples retained their cubic morphology after loading onto the $\mathrm{SiO}_{2}$ supports, and no aggregation was observed in the scope. TEM images of all the five samples treated by $\mathrm{H}_{2}, \mathrm{O}_{2}$, and $\mathrm{H}_{2}-\mathrm{O}_{2}$ atmospheres are shown in Figs S4-S6, respectively. From these
TEM images, no aggregation of particles was observed, but the cubic particles gradually turned round while only a few of particles retained the cubic morphology. It was demonstrated that the particles anchored onto the support after the successive ultrasonic and thermal treatments. So the size factor was controlled the same by the atmosphere treatments. However, due to the instability of high-unsaturated corner sites, the cubic particles finally turned thermodynamic-favored sphere after the thermal annealing. Nevertheless, all the shapes were still uniform after the atmosphere treatments anyhow. Furthermore, it has been demonstrated that both of $\mathrm{Rh}$ and $\mathrm{Pd}$ are structure-insensitive catalysts to CO oxidation $[43,44]$, so the shape evolution upon thermal treatments did not affect much on the activity. Hence, the thermal stability tests confirmed that the size and shape factors during the atmosphere treatments could be excluded in the following discussion.

\section{In-situ studies of composition-varied Pd-Rh bimetallic NCs under reaction conditions with AP-XPS}

To identify the active phase of catalysts in $\mathrm{CO}$ oxidation reaction condition, the evolution of the surface chemistry of Pd-Rh bimetallic catalysts under reaction conditions was tracked with AP-XPS. The XPS spectra obtained at room temperature under $\mathrm{H}_{2}$ atmosphere represented the surface chemistry status of the NCs before the pretreatments and reactions. For the data collected with the $\mathrm{H}_{2}$ or $\mathrm{O}_{2}$ pretreatment conditions, the catalyst remained in the flowing gas of $\mathrm{H}_{2}$ or $\mathrm{O}_{2}$ with a pressure of 0.5 Torr at $280^{\circ} \mathrm{C}$ for $1 \mathrm{~h}$ prior to the acquisition of the XPS spectra. For operando studies during the $\mathrm{CO}$ oxidation, the catalyst remained in a flowing mixture of $\mathrm{CO}$ and $\mathrm{O}_{2}$ with a pressure of 0.4 Torr $\mathrm{CO}$ and 1.0 Torr $\mathrm{O}_{2}$ in the cell. All original XPS data giving surface composition and oxidation state in this work were collected while the catalysts were in the gas phase and temperature as marked.

The as-synthesized $\mathrm{Pd}_{0.8} \mathrm{Rh}_{0.2} \mathrm{NC}$ catalyst was partially oxidized at room temperature. Fig. 2 shows the photoemission feature of $\mathrm{Pd} 3 \mathrm{~d}_{5 / 2}$ and $\mathrm{Rh} 3 \mathrm{~d}_{5 / 2}$ of $\mathrm{Pd}_{0.8} \mathrm{Rh}_{0.2} \mathrm{NC}$ catalyst at different reaction conditions and during catalysis. After annealing with $\mathrm{H}_{2}$ at $280^{\circ} \mathrm{C}$, the catalyst is termed $\mathrm{Pd}_{0.8} \mathrm{Rh}_{0.2}-\mathrm{H}_{2}$ here. Its binding energy of $\mathrm{Pd} 3 \mathrm{~d}_{5 / 2}$ shifted from 335.3 to $335.6 \mathrm{eV}$ (Fig. 2al and 2a2). This shift was likely due to the formation of Pd hydride when the catalyst was exposed to $\mathrm{H}_{2}$ at an elevated temperature. The $0.3 \mathrm{eV}$ upshift of binding energy of $\mathrm{Pd} 3 \mathrm{~d}_{5 / 2}$ for $\mathrm{Pd}$ hydride agreed well with literatures [45,46]. After $\mathrm{H}_{2}$ treatment, the catalyst was cooled down to room temperature in $\mathrm{H}_{2}$. Then, a mixture of $\mathrm{CO}$ and $\mathrm{O}_{2}$ was in- 

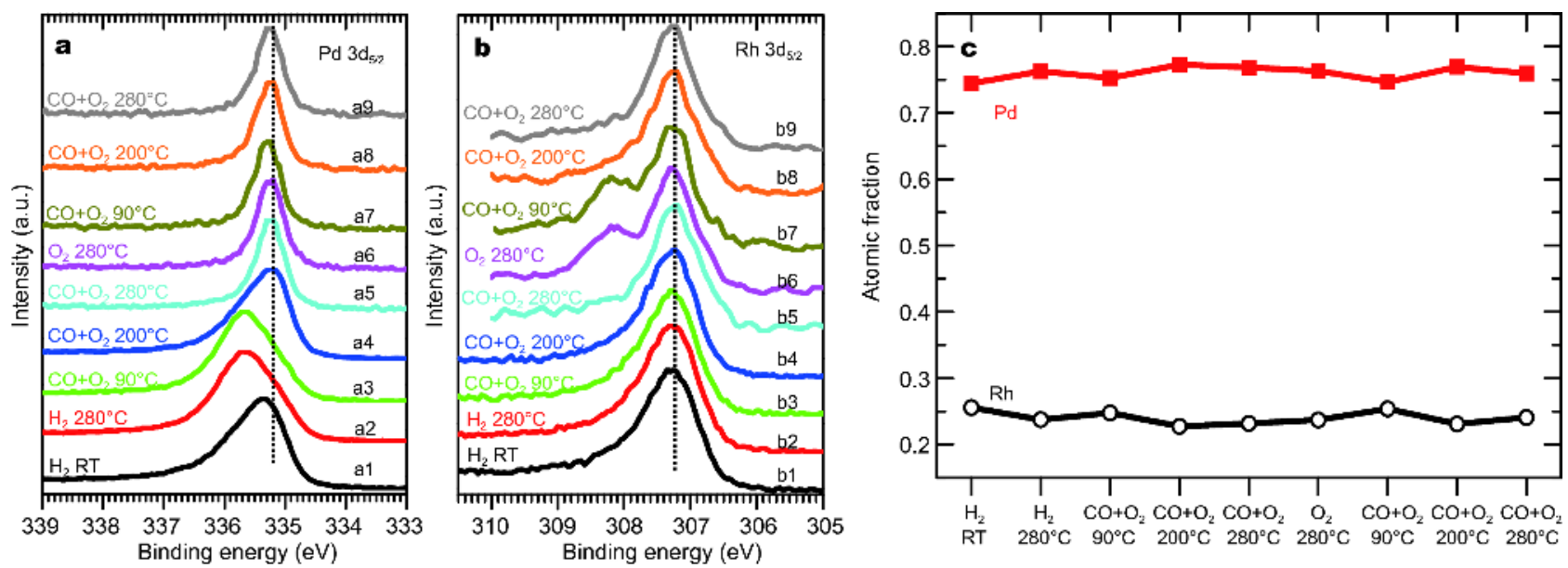

Figure 2 The photoemission feature of $\mathrm{Pd}_{3} 3 \mathrm{~d}_{5 / 2}$ (a) and $\mathrm{Rh} 3 \mathrm{~d}_{5 / 2}$ (b) of $\mathrm{Pd}_{0.8} \mathrm{Rh}_{0.2} \mathrm{NCs}$ catalyst during CO oxidation after $\mathrm{H}_{2}$ pretreatment and $\mathrm{H}_{2}$ -reaction $-\mathrm{O}_{2}$ treatment. Evolution of atomic fraction of $\mathrm{Pd}$ and $\mathrm{Rh}$ during catalysis (c).

troduced into the reaction cell and kept flowing through $\mathrm{Pd}_{0.8} \mathrm{Rh}_{0.2}-\mathrm{H}_{2}$; the catalyst during $\mathrm{CO}$ oxidation is termed as $\mathrm{Pd}_{0.8} \mathrm{Rh}_{0.2}-\mathrm{H}_{2}-\mathrm{CO}$ oxidation. Along with the increase of catalysis temperature of $\mathrm{CO}$ oxidation (Fig. 2b3-2b5), the XPS spectra collected at different temperatures showed that $\mathrm{Rh}$ remained as metallic while Pd changed from Pd hydride to metallic Pd (Fig. 2a3-2a5).

After the $\mathrm{CO}$ oxidation at $280^{\circ} \mathrm{C}, \mathrm{CO}$ was purged and the catalyst was further treated with $\mathrm{O}_{2}$ at $280^{\circ} \mathrm{C}$, termed as $\mathrm{Pd}_{0.8} \mathrm{Rh}_{0.2}-\mathrm{H}_{2}-\mathrm{CO}$ oxidation $-\mathrm{O}_{2}$. $\mathrm{Rh} 3 \mathrm{~d}$ spectra of $\mathrm{Pd}_{0.8} \mathrm{Rh}_{0.2}-\mathrm{H}_{2}-\mathrm{CO}$ oxidation after $\mathrm{O}_{2}$ treatment clearly showed that $\mathrm{Rh}$ was partially oxidized, as evidenced by the appearance of a peak at $308.2 \mathrm{eV}$ (Fig. 2b6) which was assigned to $\mathrm{RhO}_{x}[47,48]$. XPS spectra of $\mathrm{Pd} 3 \mathrm{~d}$ of $\mathrm{Pd}_{0.8}$ $\mathrm{Rh}_{0.2}-\mathrm{H}_{2}-\mathrm{CO}$ oxidation $-\mathrm{O}_{2}$ showed that $\mathrm{Pd}$ remained as a metallic state after treated with $\mathrm{O}_{2}$ at $280^{\circ} \mathrm{C}$ (Fig. 2a6). The lack of $\mathrm{Pd}$ oxide and the appearance of $\mathrm{RhO}_{x}$ on $\mathrm{Pd}_{0.8} \mathrm{Rh}_{0.2}-\mathrm{H}_{2}-\mathrm{CO}$ oxidation $-\mathrm{O}_{2}$ (Fig. $2 \mathrm{~b} 6$ and $2 \mathrm{a} 6$ ) suggested that $\mathrm{RhO}_{x}$ covered the surface after $\mathrm{H}_{2}-\mathrm{CO}$ oxidation $-\mathrm{O}_{2}$ treatment. After this treatment, a flowing mixture of $\mathrm{CO}$ and $\mathrm{O}_{2}$ was introduced and $\mathrm{CO}$ oxidation was performed on $\mathrm{Pd}_{0.8} \mathrm{Rh}_{0.2}-\mathrm{H}_{2}-\mathrm{CO}$ oxidation- $\mathrm{O}_{2}$ again. In the mixture of $\mathrm{CO}$ and $\mathrm{O}_{2}$ at $200^{\circ} \mathrm{C}, \mathrm{RhO}_{x}$ was reduced back to metallic Rh (Fig. 2b8). As shown in Fig. 2c, there was no significant change in the surface atomic fraction of $\mathrm{Rh}$ and $\mathrm{Pd}$, indicating that surface segregation did not happen in the well-shaped $\mathrm{Pd}_{0.8} \mathrm{Rh}_{0.2} \mathrm{NPs}$.

Notably, when the treatment protocol was changed from $\mathrm{H}_{2}-\mathrm{CO}$ oxidation $-\mathrm{O}_{2}$ to $\mathrm{H}_{2}-\mathrm{O}_{2}$, the active phase of the $\mathrm{Pd}_{0.8} \mathrm{Rh}_{0.2}$ during $\mathrm{CO}$ oxidation $\left(\mathrm{Pd}_{0.8} \mathrm{Rh}_{0.2}-\mathrm{H}_{2}-\mathrm{CO}\right.$ oxidation $-\mathrm{O}_{2}$ ) was completely different. As shown in Fig. 3a2, Pd hydrides formed on $\mathrm{Pd}_{0.8} \mathrm{Rh}_{0.2}-\mathrm{H}_{2}$ (i.e., $\mathrm{Pd}_{0.8} \mathrm{Rh}_{0.2}$ treated with $\mathrm{H}_{2}$ ). After the following treatment with $\mathrm{O}_{2}$ (Fig. 3a3), Pd 3d spectrum of $\mathrm{Pd}_{0.8} \mathrm{Rh}_{0.2}-\mathrm{H}_{2}-\mathrm{O}_{2}$ does not have the photoemission feature of Pd hydride at $335.6 \mathrm{eV}$. Alternatively, a new intense peak at $336.7 \mathrm{eV}$ appeared in Pd $3 \mathrm{~d}$ of $\mathrm{Pd}_{0.8} \mathrm{Rh}_{0.2}-\mathrm{H}_{2}-\mathrm{O}_{2}$ (Fig. 3a3), which was probably assigned to $\mathrm{PdO}_{x}$ based on prior reports [49-51]. The $\mathrm{Pd}$ $3 \mathrm{~d}_{5 / 2}$ peak of the formed $\mathrm{PdO}_{x}$ remained in the temperature range of $90-280^{\circ} \mathrm{C}$ (Fig. 3a4-3a10). During CO oxidation in the temperature range of $90-280^{\circ} \mathrm{C}$ (Fig. 3b4-3b10), oxidized $\mathrm{Rh}$ of $\mathrm{Pd}_{0.8} \mathrm{Rh}_{0.2}-\mathrm{H}_{2}-\mathrm{O}_{2}$ was progressively reduced to metallic $\mathrm{Rh}$. It suggested that the active surface of $\mathrm{Pd}_{0.8} \mathrm{Rh}_{0.2}-\mathrm{H}_{2}-\mathrm{O}_{2}-\mathrm{CO}$ oxidation consists of both $\mathrm{Rh}$ and $\mathrm{PdO}_{x}$ during $\mathrm{CO}$ oxidation. Hence, the active surface of $\mathrm{Pd}_{0.8} \mathrm{Rh}_{0.2}-\mathrm{H}_{2}-\mathrm{O}_{2}-\mathrm{CO}$ oxidation was different from that of $\mathrm{Pd}_{0.8} \mathrm{Rh}_{0.2}-\mathrm{H}_{2}-\mathrm{CO}$ oxidation- $\mathrm{O}_{2}$ (Fig. 2a8, 2a9, $2 \mathrm{~b} 8$ and 2b9) during $\mathrm{CO}$ oxidation at 200$280^{\circ} \mathrm{C}$, as the protocols of pretreatments before $\mathrm{CO}$ oxidation $\left(\mathrm{H}_{2}-\mathrm{CO}\right.$ oxidation $-\mathrm{O}_{2}$ versus $\left.\mathrm{H}_{2}-\mathrm{O}_{2}\right)$ were different. These parallel studies using slight different protocols of treatment on the same $\mathrm{Pd}_{0.8} \mathrm{Rh}_{0.2}$ NCs (Figs 2 and 3) suggested that different pretreatment conditions could tailor surface active phases of the same catalyst significantly.

Similar to $\mathrm{Pd}_{0.8} \mathrm{Rh}_{0.2}$ (Figs 2 and 3), our in-situ studies of $\mathrm{Pd}_{0.6} \mathrm{Rh}_{0.4} \mathrm{NCs}$ under pretreatment and during catalysis by AP-XPS showed that surface composition and valence state of $\mathrm{Pd}_{0.6} \mathrm{Rh}_{0.4}$ NCs during $\mathrm{CO}$ oxidation also depended on their pretreatment conditions. Fig. 4 shows the photoemission features of $\mathrm{Pd} 3 \mathrm{~d}_{5 / 2}$ and $\mathrm{Rh} 3 \mathrm{~d}_{5 / 2}$ of $\mathrm{Pd}_{0.6}$ $\mathrm{Rh}_{0.4} \mathrm{NCs}$ which experienced a sequential pretreatment at $280^{\circ} \mathrm{C}$ in $\mathrm{H}_{2}$, a mixture of $\mathrm{CO}$ and $\mathrm{O}_{2}, \mathrm{O}_{2}$ at $280^{\circ} \mathrm{C}$, and then the mixture of $\mathrm{CO}$ and $\mathrm{O}_{2}$ again. After $\mathrm{H}_{2}$ pre- 

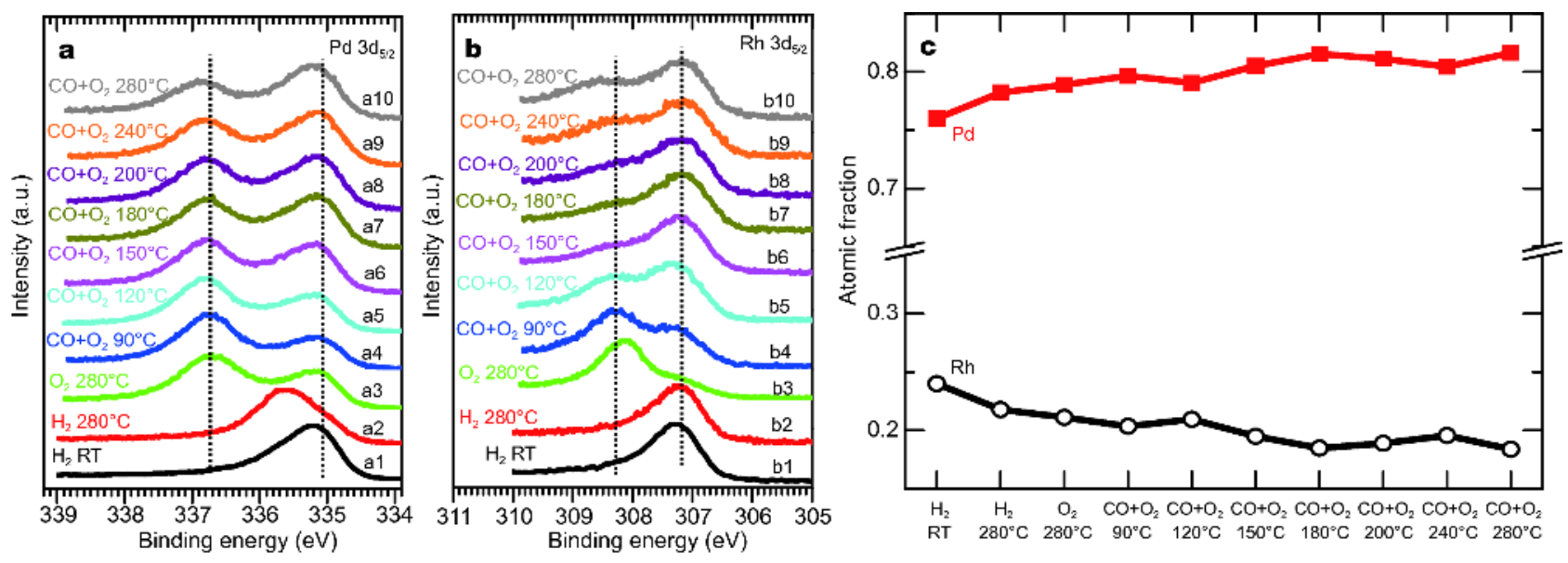

Figure 3 The photoemission feature of $\mathrm{Pd} 3 \mathrm{~d}_{5 / 2}$ (a) and $\mathrm{Rh} 3 \mathrm{~d}_{5 / 2}$ (b) of $\mathrm{Pd}_{0.8} \mathrm{Rh}_{0.2} \mathrm{NCs}$ catalyst during CO oxidation after $\mathrm{H}_{2}$ at $280^{\circ} \mathrm{C}$ and then $\mathrm{O}_{2}$ at $280^{\circ} \mathrm{C}$ pretreatment. Evolution of atomic fraction of $\mathrm{Pd}$ and $\mathrm{Rh}$ during catalysis (c).
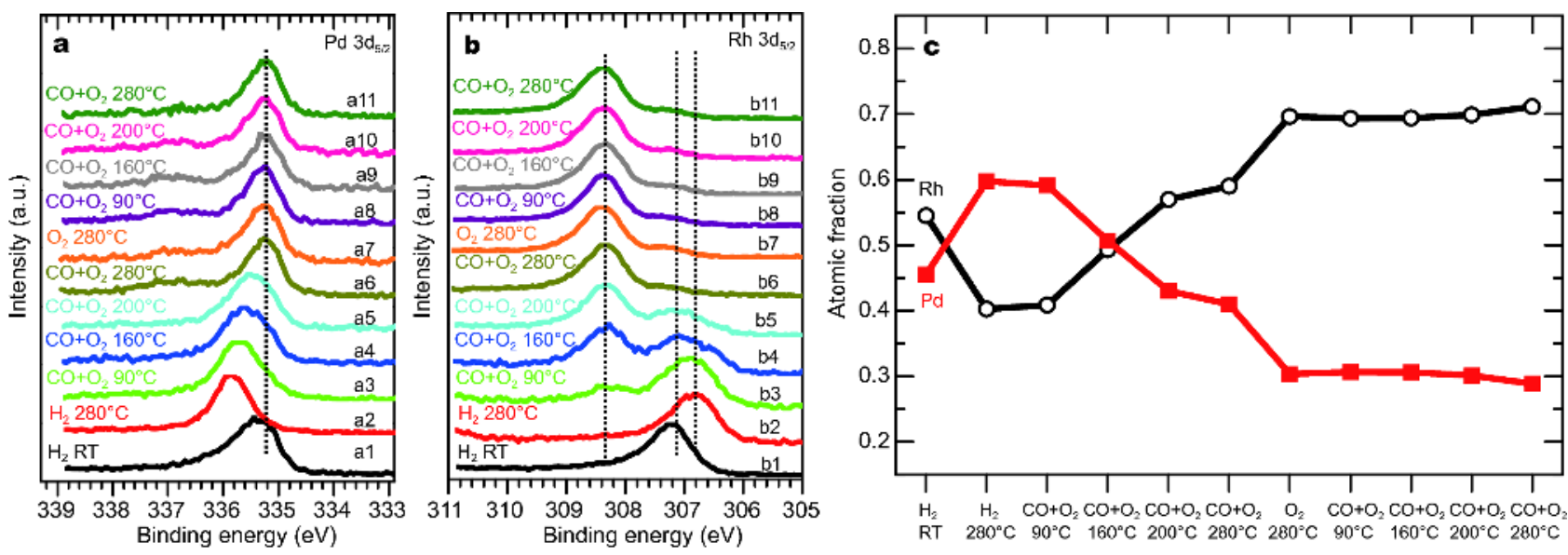

Figure 4 The photoemission feature of $\mathrm{Pd}_{3} 3 \mathrm{~d}_{5 / 2}$ (a) and $\mathrm{Rh} 3 \mathrm{~d}_{5 / 2}$ (b) of $\mathrm{Pd}_{0.6} \mathrm{Rh}_{0.4} \mathrm{NCs}$ catalyst during CO oxidation after $\mathrm{H}_{2}$ pretreatment and $\mathrm{H}_{2}$ -reaction $-\mathrm{O}_{2}$ treatment. Evolution of atomic fraction of $\mathrm{Pd}$ and $\mathrm{Rh}$ during catalysis (c).

treatment at $280^{\circ} \mathrm{C}$ (Fig. 4a2), the photoemission feature of $\mathrm{Pd}$ of $\mathrm{Pd}_{0.6} \mathrm{Rh}_{0.4}-\mathrm{H}_{2}$ showed that $\mathrm{Pd}$ was hydrogenated to Pd hydrides due to a significant upshift by $0.5 \mathrm{eV}$ compared to the metallic state. However, the $\mathrm{Rh} 3 \mathrm{~d}_{5 / 2}$ of $\mathrm{Pd}_{0.6} \mathrm{Rh}_{0.4}-\mathrm{H}_{2}$ downshifts by $0.4 \mathrm{eV}$ (Fig. $4 \mathrm{~b} 2$ ). The two simultaneous opposite shifts of $\mathrm{Rh} 3 \mathrm{~d}_{5 / 2}$ (Fig. 4b2) and $\mathrm{Pd}$ $3 \mathrm{~d}_{5 / 2}$ (Fig. 4a2) of $\mathrm{Pd}_{0.6} \mathrm{Rh}_{0.4}-\mathrm{H}_{2}$ clearly showed that the electrons were transferred from $\mathrm{Pd}$ hydride to $\mathrm{Rh}$ due to the $\mathrm{H}_{2}$ treatment. The unexpected low $\mathrm{Rh} 3 \mathrm{~d}$ of binding energy at $306.8 \mathrm{eV}$ of $\mathrm{Pd}_{0.6} \mathrm{Rh}_{0.4}-\mathrm{H}_{2}$ was a solid evidence that the electrons of $\mathrm{Pd}$ hydrides were transferred to $\mathrm{Rh}$ atoms. This pretreatment formed a mixture of $\mathrm{Rh}$ and $\mathrm{Pd}$ hydride.

After the introduction of a mixture of $\mathrm{CO}$ and $\mathrm{O}_{2}$, the surface of $\mathrm{Pd}_{0.6} \mathrm{Rh}_{0.4}-\mathrm{H}_{2}$ experienced a significant change even at $90-120^{\circ} \mathrm{C} . \mathrm{Pd} 3 \mathrm{~d}_{5 / 2}$ of palladium hydride in the mixture of $\mathrm{CO}$ and $\mathrm{O}_{2}$ progressively downshift to metallic Pd (Fig. 4a3-4a6); this downshift probably resulted from the oxidation of palladium hydride to metallic $\mathrm{Pd}$. Meanwhile, negatively charged $\mathrm{Rh}$ was progressively oxidized as shown in Fig. 4b3-4b6. In terms of the status of $\mathrm{CO}$ oxidation at $280^{\circ} \mathrm{C}$ (Fig. $4 \mathrm{a} 6$ and $4 \mathrm{~b} 6$ ), the active surface consisted of $\mathrm{RhO}_{x}$ and metallic Pd. Under the sequential $\mathrm{O}_{2}$ atmosphere at $280^{\circ} \mathrm{C}$ (Fig. $4 \mathrm{a} 7$ and $4 \mathrm{~b} 7$ ), there was no obvious change in the valence states of $\mathrm{Pd}$ and Rh. It suggested that metallic $\mathrm{Pd}$ of $\mathrm{Pd}_{0.6} \mathrm{Rh}_{0.4}-\mathrm{H}_{2}-\mathrm{CO}$ oxidation $-\mathrm{O}_{2}$ was in the subsurface covered by $\mathrm{RhO}_{x}$. Since metallic Pd in subsurface was observed by the surface sensitive AP-XPS technique, the thickness of $\mathrm{RhO}_{x}$ should be less than $2 \mathrm{~nm}$. Then, $\mathrm{Pd}_{0.6} \mathrm{Rh}_{0.4}-\mathrm{H}_{2}-\mathrm{CO}$ 

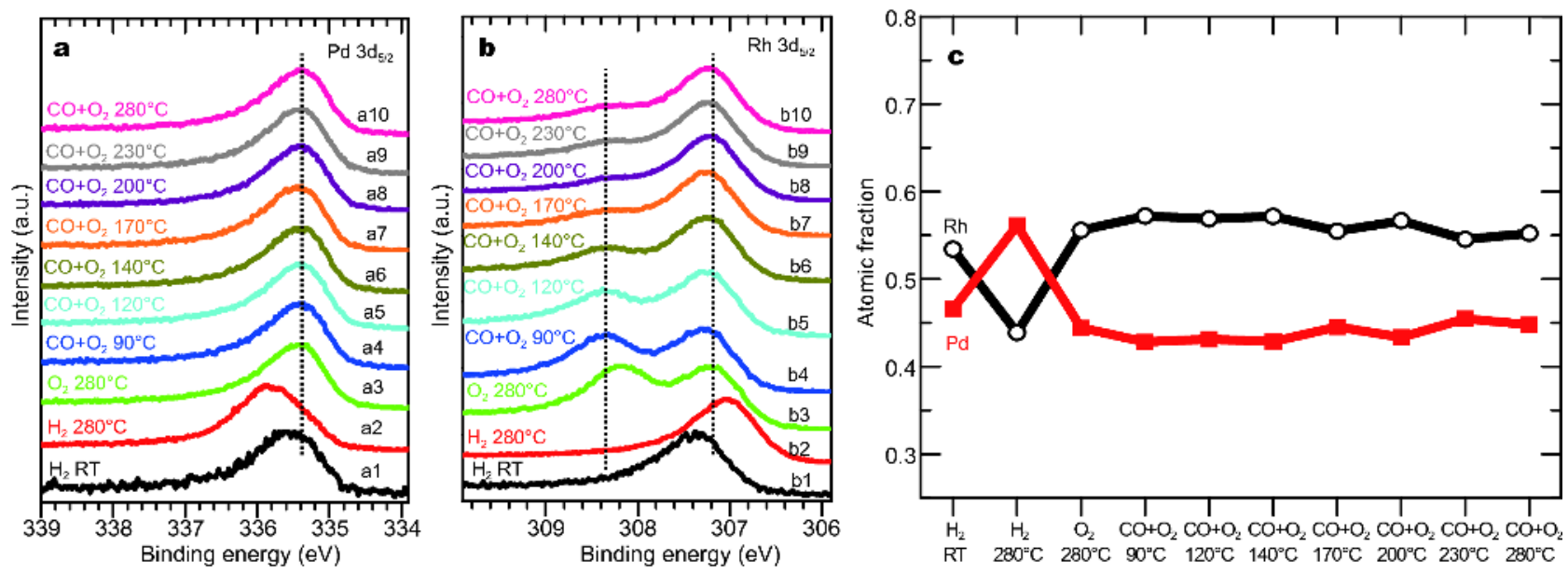

Figure 5 The photoemission feature of $\mathrm{Pd} 3 \mathrm{~d}_{12}$ (a) and $\mathrm{Rh} 3 \mathrm{~d}_{5 / 2}$ (b) of $\mathrm{Pd}_{0.6} \mathrm{Rh}_{0.4} \mathrm{NCs}$ catalyst during CO oxidation after $\mathrm{H}_{2}-\mathrm{O}_{2}$ treatment. Evolution of atomic fraction of Pd and Rh during catalysis (c).

oxidation $-\mathrm{O}_{2}$ exposed to the mixture of $\mathrm{CO}$ and $\mathrm{O}_{2}$ again; at this state, the catalyst was termed as $\mathrm{Pd}_{0.6} \mathrm{Rh}_{0.4}-\mathrm{H}_{2}-\mathrm{CO}$ oxidation $-\mathrm{O}_{2}-\mathrm{CO}$ oxidation (Fig. 4a8-4a11 and $4 \mathrm{~b} 8-$ $4 \mathrm{~b} 11)$. Its photoemission feature and surface composition at this temperature range $\left(90-280^{\circ} \mathrm{C}\right)$ were the same as that of $\mathrm{Pd}_{0.6} \mathrm{Rh}_{0.4}-\mathrm{H}_{2}-\mathrm{CO}$ oxidation $-\mathrm{O}_{2}$ before $\mathrm{CO}$ oxidation. Thus, the active phase of $\mathrm{Pd}_{0.6} \mathrm{Rh}_{0.4}-\mathrm{H}_{2}-\mathrm{CO}$ oxidation $-\mathrm{O}_{2}-\mathrm{CO}$ oxidation during $\mathrm{CO}$ oxidation in the temperature range of $90-280^{\circ} \mathrm{C}$ (Fig. $4 \mathrm{a} 8-4 \mathrm{a} 11$ and $4 \mathrm{~b} 8-$ 4b11) was $\mathrm{RhO}_{x}$. And the composition and valence state of the active surface of $\mathrm{Pd}_{0.6} \mathrm{Rh}_{0.4}-\mathrm{H}_{2}-\mathrm{CO}$ oxidation- $\mathrm{O}_{2}$ $-\mathrm{CO}$ oxidation in this temperature range remained constant (Fig. 4c).

As the quantitative analyses of $\mathrm{Pd}_{0.6} \mathrm{Rh}_{0.4}$ under different conditions, surface compositions of $\mathrm{Rh}$ and $\mathrm{Pd}$ during these treatments and catalysis conditions were analyzed. As shown in Fig. 4c, atomic fraction of Rh and Pd exhibited significant change along with the change of reaction conditions. The decrease of atomic fraction of $\mathrm{Rh}$ in the step of $\mathrm{H}_{2}$ pretreatment at $90-280^{\circ} \mathrm{C}$ (Fig. 4c) was attributed to the formation of palladium hydride in surface region and the immigration of $\mathrm{Rh}$ to deep layers (Fig. $4 \mathrm{a} 1,4 \mathrm{a} 2,4 \mathrm{~b} 1$ and $4 \mathrm{~b} 2$ ). The significant restructuring of this alloy by $\mathrm{H}_{2}$ was driven by two factors: (1) Rh has a higher surface energy than Pd, and (2) Pd can form palladium hydride but rhodium cannot. Then, when the atmosphere was switched from $\mathrm{H}_{2}$ to $\mathrm{CO}+\mathrm{O}_{2}$, the atomic fraction of $\mathrm{Rh}$ in the mixture of $\mathrm{CO}$ and $\mathrm{O}_{2}$ continuously increased with the increase of reaction temperature (Fig. 4c). Although palladium hydride could be readily oxidized to a metallic state, it was not further oxidized to $\mathrm{PdO}_{x}$ during $\mathrm{CO}$ oxidation (Fig. $4 \mathrm{a} 3-4 \mathrm{a} 6$ and $4 \mathrm{~b} 3-4 \mathrm{~b} 6$ ); this was because the formation of rhodium oxide in the mixture of $\mathrm{CO}$ and $\mathrm{O}_{2}$ was more thermodynamically favorable than the formation of palladium oxide. As shown in Fig. 4b3-4b6, Rh atoms were preferentially oxidized to rhodium oxide; thus, the atomic fraction of $\mathrm{Rh}$ was continuously increased. The preferential formation of rhodium oxide on surface prevented palladium from being further oxidized to palladium oxide. Thus, the active phase of $\mathrm{Pd}_{0.6} \mathrm{Rh}_{0.4}-\mathrm{H}_{2}-\mathrm{CO}$ oxidation was $\mathrm{RhO}_{x}$ instead of metallic Pd or Rh.

Fig. 5 shows the XPS spectra of Pd $3 d_{5 / 2}$ and Rh $3 d_{5 / 2}$ of $\mathrm{Pd}_{0.6} \mathrm{Rh}_{0.4} \mathrm{NCs}$ under another set of pretreatment conditions $\left(\mathrm{H}_{2}-\mathrm{O}_{2}\right)$. Compared with the previous pretreatment of $\mathrm{H}_{2}-\mathrm{CO}$ oxidation $-\mathrm{O}_{2}$, the treatment of $\mathrm{Pd}_{0.6} \mathrm{Rh}_{0.4} \mathrm{NCs}$ in Fig. 5 did not build the step of $\mathrm{CO}$ oxidation between the treatment in $\mathrm{H}_{2}$ and that in $\mathrm{O}_{2}$. As shown in Fig. 5a1, $5 \mathrm{a} 2,5 \mathrm{~b} 1$ and $5 \mathrm{~b} 2$, after $\mathrm{H}_{2}$ pretreatment, Pd was hydrogenated to Pd hydrides; the downshift of Rh $3 \mathrm{~d}$ by $0.4 \mathrm{eV}$ suggested the charge transfer from Pd hydrides to metallic $\mathrm{Rh}$ and thus formed negatively charged $\mathrm{Rh}$ atoms. $\mathrm{O}_{2}$ was introduced to the reaction cell of $\mathrm{Pd}_{0.6} \mathrm{Rh}_{0.4}-\mathrm{H}_{2}$, forming $\mathrm{Pd}_{0.6} \mathrm{Rh}_{0.4}-\mathrm{H}_{2}-\mathrm{O}_{2}$. Upon the $\mathrm{O}_{2}$ treatment, $\mathrm{Pd}$ hydrides were changed into metallic Pd via an oxidation process of palladium hydride to metallic $\mathrm{Pd}$. However, compared to the formation of $\mathrm{RhO}_{x}$ of $\mathrm{Pd}_{0.6} \mathrm{Rh}_{0.4}$ at the step of $\mathrm{O}_{2}$ at $280^{\circ} \mathrm{C}$ (Fig. $4 \mathrm{~b} 7$ ) after the treatment of $\mathrm{H}_{2}$ - $\mathrm{CO}$ oxidation $\left(\mathrm{Pd}_{0.6} \mathrm{Rh}_{0.4}-\mathrm{H}_{2}-\mathrm{CO}\right.$ oxidation $\left.-\mathrm{O}_{2}\right)$, the $\mathrm{Rh}$ $3 \mathrm{~d}$ of $\mathrm{Pd}_{0.6} \mathrm{Rh}_{0.4}$ at the step of $\mathrm{O}_{2}$ at $280^{\circ} \mathrm{C}\left(\mathrm{Pd}_{0.6} \mathrm{Rh}_{0.4}-\mathrm{H}_{2}\right.$ $-\mathrm{O}_{2}$ ) was in a metallic state. This distinctive difference between the oxidizing state of $\mathrm{Rh}$ in $\mathrm{RhO}_{x}$ of $\mathrm{Pd}_{0.6} \mathrm{Rh}_{0.4}$ $-\mathrm{H}_{2}-\mathrm{CO}$ oxidation $-\mathrm{O}_{2}$ (Fig. $4 \mathrm{~b} 2-4 \mathrm{~b} 6$ ) and the metallic state of $\mathrm{Rh}$ of $\mathrm{Pd}_{0.6} \mathrm{Rh}_{0.4}-\mathrm{H}_{2}-\mathrm{O}_{2}$ after only $\mathrm{H}_{2}$ (Fig. $5 \mathrm{~b} 2$ ) 

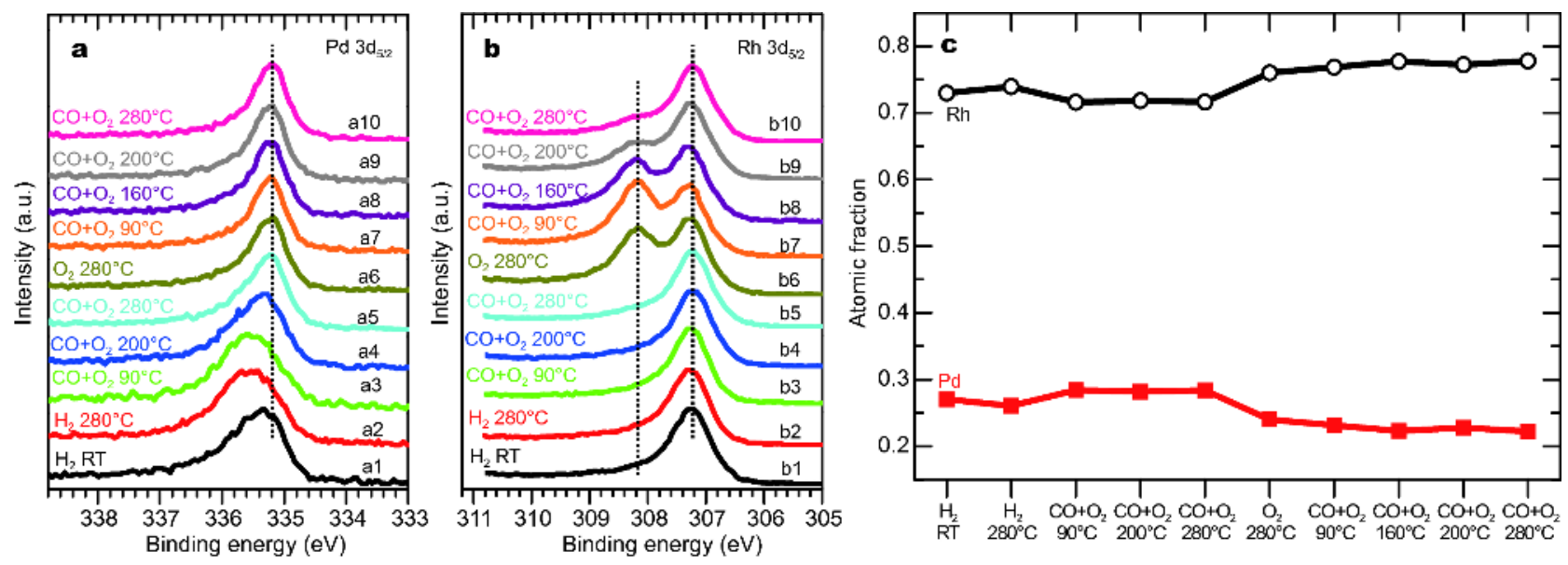

Figure 6 The photoemission feature of $\mathrm{Pd} 3 \mathrm{~d}_{5 / 2}$ (a) and $\mathrm{Rh} 3 \mathrm{~d}_{5 / 2}$ (b) of $\mathrm{Pd}_{0.2} \mathrm{Rh}_{0.8} \mathrm{NCs}$ catalyst during CO oxidation after $\mathrm{H}_{2}$ pretreatment and $\mathrm{H}_{2}$ -reaction $-\mathrm{O}_{2}$ treatment. Evolution of atomic fraction of $\mathrm{Pd}$ and $\mathrm{Rh}$ during catalysis (c).

was probably related to their different surface structures. As shown in Fig. 4c, the atomic fraction of Rh of surface $\mathrm{Pd}_{0.6} \mathrm{Rh}_{0.4}-\mathrm{H}_{2}-\mathrm{CO}$ oxidation $-\mathrm{O}_{2}$ was about $56 \%$ and all measured $\mathrm{Rh}$ atoms were at oxidizing state; obviously, the surface region consisted of $\mathrm{RhO}_{x}$ shell and metallic $\mathrm{Pd}$ subsurface. In the case of $\mathrm{Pd}_{0.6} \mathrm{Rh}_{0.4}-\mathrm{H}_{2}-\mathrm{O}_{2}$, both $\mathrm{Pd}$ and $\mathrm{Rh}$ were observed and at metallic state, suggesting that $\mathrm{Rh}$ and $\mathrm{Pd}$ atoms existed in alloy. As illustrated in Fig. 5c, significant surface segregation was also observed for the $\mathrm{Pd}_{0.6} \mathrm{Rh}_{0.4} \mathrm{NCs}$ under this $\mathrm{H}_{2}-\mathrm{O}_{2}$ pretreatment condition. The overall composition probably affected the energy barrier of surface segregation.

Overall, for the sample of $\mathrm{Pd}_{0.6} \mathrm{Rh}_{0.4} \mathrm{NCs}$, the active phase during $\mathrm{CO}$ oxidation after the $\mathrm{H}_{2}-\mathrm{O}_{2}$ treatment was $\mathrm{Pd}_{0.45} \mathrm{Rh}_{0.55}$ alloy (Fig. 5a2-5a10, 5b7-5b10, and 5c). However, it was $\mathrm{RhO}_{x}$ after the treatment of $\mathrm{H}_{2}-$ reaction $-\mathrm{O}_{2}$ (Fig. 4b8-4b11). This difference suggested that different active phases could be generated from the same assynthesized catalyst if a different treatment was used. It further suggested that a specific pretreatment condition could be chosen to generate an active phase which could exhibit a different catalytic performance.

Photoemission features of $\mathrm{Pd} 3 \mathrm{~d}_{5 / 2}$ and $\mathrm{Rh} 3 \mathrm{~d}_{5 / 2}$ of $\mathrm{Pd}_{0.2} \mathrm{Rh}_{0.8} \mathrm{NCs}$ catalyst during pretreatments and $\mathrm{CO}$ oxidation were tracked as shown in Fig. 6. Apparently, both $\mathrm{Pd}$ and $\mathrm{Rh}$ of the catalyst at $280^{\circ} \mathrm{C}$ in the mixture of $\mathrm{CO}$ and $\mathrm{O}_{2}$ after treatment in $\mathrm{H}_{2}$ maintained in metallic states. After subsequently annealing at $280^{\circ} \mathrm{C}$ in $\mathrm{O}_{2}$ (Fig. $6 \mathrm{a} 6$ and 6b6), about half of $\mathrm{Rh}$ was oxidized to $\mathrm{RhO}_{x}$ but all $\mathrm{Pd}$ atoms remained at metallic state. However, in the temperature range of $90-200^{\circ} \mathrm{C}, \mathrm{RhO}_{x}$ was gradually reduced back to metallic Rh during the $\mathrm{CO}$ oxidation. Thus, the active phase of the catalysts during $\mathrm{CO}$ oxidation at $180-280^{\circ} \mathrm{C}$ after treatment of $\mathrm{H}_{2}-$ reaction $-\mathrm{O}_{2}$ was the $\mathrm{Pd}_{0.25} \mathrm{Rh}_{0.75}$. As shown in Fig. 6c, no significant surface segregation took place during the pretreatment and the $\mathrm{CO}$ oxidation.

Fig. 7 shows photoemission features of $\mathrm{Pd} 3 \mathrm{~d}_{5 / 2}$ and $\mathrm{Rh}$ $3 \mathrm{~d}_{5 / 2}$ of $\mathrm{Pd}_{0.2} \mathrm{Rh}_{0.8}$ NCs catalyst during $\mathrm{CO}$ oxidation reaction after a treatment of $\mathrm{H}_{2}-\mathrm{O}_{2}$. Pd remained in metallic state after the treatment of $\mathrm{H}_{2}-\mathrm{O}_{2}$ (Fig. 7a3), while $\mathrm{Rh}$ was partially oxidized to Rh oxides (Fig. $7 \mathrm{~b} 3$ ). In the following $\mathrm{CO}$ oxidation reaction, $\mathrm{Pd}$ remained at metallic state and Rh oxide was gradually reduced to metallic with the increase of temperature. Similarly, there was no significant change in the atomic fraction of $\mathrm{Pd}$ and $\mathrm{Rh}$ on the surface. Hence, the active phase during $\mathrm{CO}$ oxidation at $200-280^{\circ} \mathrm{C}$ after $\mathrm{H}_{2}-\mathrm{O}_{2}$ treatment was $\mathrm{Pd}_{0.35} \mathrm{Rh}_{0.65}$ alloy.

Unlike the previous two cases, $\mathrm{Pd}_{0.2} \mathrm{Rh}_{0.8}$ NCs exhibited the same metallic alloy reaction sites (slightly different in composition) to $\mathrm{CO}$ oxidation upon the two pretreatment conditions $\left(\mathrm{H}_{2}-\right.$ reaction $-\mathrm{O}_{2}-$ reaction, and $\mathrm{H}_{2}-\mathrm{O}_{2}-$ reaction) without significant surface segregation.

\section{Apparent activation energies of Pd-Rh NCs in CO oxidation}

To measure activation barriers of $\mathrm{CO}$ oxidation on these catalysts, $\mathrm{CO}$ oxidation was performed in the kinetically controlled region (the conversion of $\mathrm{CO} \leq 15 \%$ ). Fig. 8 presents the Arrhenius plots of $\mathrm{Pd}_{x} \mathrm{Rh}_{1-x}$ bimetallic NCs, $\mathrm{Pd}_{0.8} \mathrm{Rh}_{0.2}, \mathrm{Pd}_{0.6} \mathrm{Rh}_{0.4}$, and $\mathrm{Pd}_{0.2} \mathrm{Rh}_{0.8}$ upon the two different pretreatment methods $\left(\mathrm{H}_{2}-\right.$ reaction $-\mathrm{O}_{2}$ versus $\left.\mathrm{H}_{2}-\mathrm{O}_{2}\right)$. Because $\mathrm{Pd}_{0.2} \mathrm{Rh}_{0.8}-\mathrm{H}_{2}$-reaction-CO and $\mathrm{Pd}_{0.2} \mathrm{Rh}_{0.8}-\mathrm{H}_{2}$ $-\mathrm{O}_{2}$ exhibited the same surface composition and the same valence state (Figs 6 and 7), only $\mathrm{Pd}_{0.2} \mathrm{Rh}_{0.8}-\mathrm{H}_{2}-\mathrm{O}_{2}$ was evaluated by the kinetic study. Table 1 lists the activation 

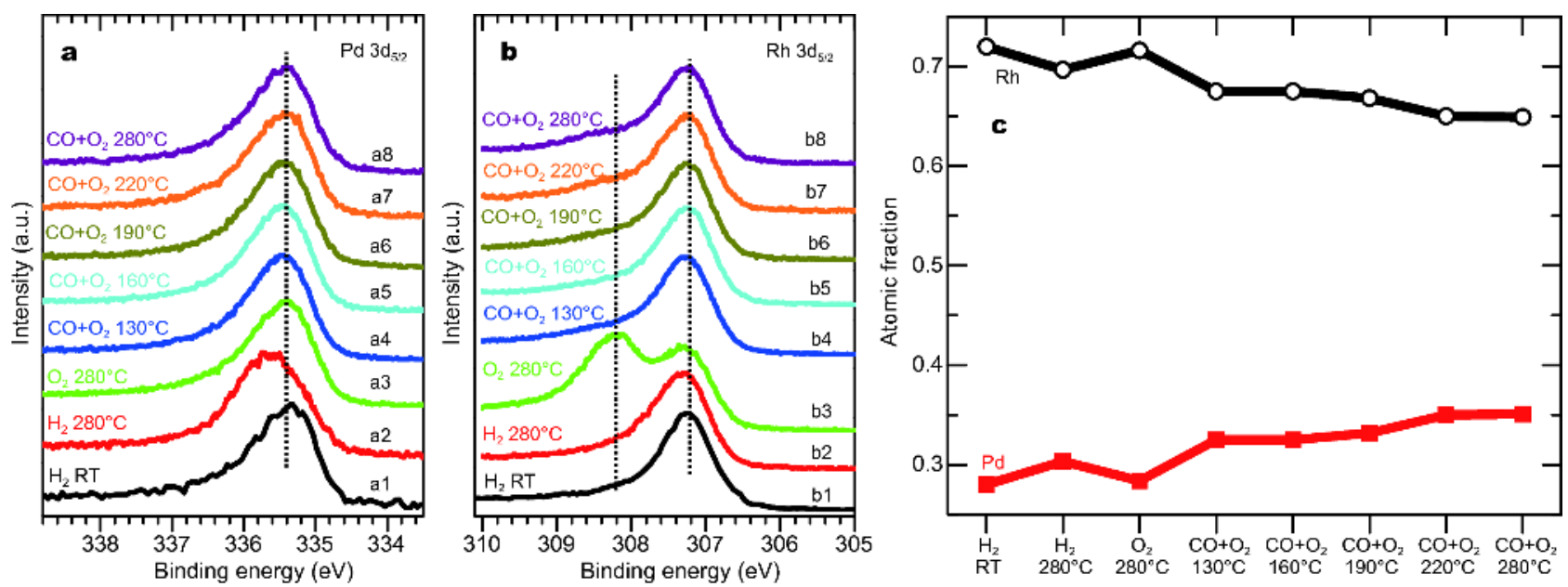

Figure 7 The photoemission feature of $\mathrm{Pd}_{3 / 2}$ (a) and $\mathrm{Rh} 3 \mathrm{~d}_{5 / 2}$ (b) of $\mathrm{Pd}_{0.2} \mathrm{Rh}_{0.8} \mathrm{NCs}$ during CO oxidation after $\mathrm{H}_{2}-\mathrm{O}_{2}$ treatment. Evolution of atomic fraction of $\mathrm{Pd}$ and $\mathrm{Rh}$ during catalysis (c).

energies calculated from the Arrhenius plots for the catalysts pretreated by different methods.

As was shown in Table 2, the activation energies of $\mathrm{CO}$ oxidation reactions catalyzed by $\mathrm{H}_{2}$ pretreated pure $\mathrm{Pd}$ NCs and pure Rh NCs were 60 and $98 \mathrm{~kJ} \mathrm{~mol}^{-1}$, respectively. The in-situ XPS study showed that the active surface phases of the as-synthesized pure Pd NCs and Rh $\mathrm{NCs}$ to $\mathrm{CO}$ oxidation were metallic $\mathrm{Pd}$ and metallic $\mathrm{Rh}$, respectively. The activation energies of metallic $\mathrm{Pd}$ and $\mathrm{Rh}$ for $\mathrm{CO}$ oxidation reaction were in qualitative agreement with the values reported in literatures [52-54].

For $\mathrm{Pd}_{0.8} \mathrm{Rh}_{0.2}$ after $\mathrm{H}_{2}-\mathrm{CO}$ oxidation- $\mathrm{O}_{2}$ pretreatment (Fig. 4), the activation energy of $\mathrm{CO}$ oxidation was $61 \mathrm{~kJ} \mathrm{~mol}^{-1}$. XPS spectra (Fig 4a8 and 4b8) showed that in this condition the active surface was $\mathrm{Pd}_{0.75} \mathrm{Rh}_{0.25}$ bimetallic alloy. The similar activation barrier for $\mathrm{CO}$ oxidation on the sample of $\mathrm{Pd}_{0.8} \mathrm{Rh}_{0.2}-\mathrm{H}_{2}-\mathrm{CO}$ oxidation $-\mathrm{O}_{2}\left(61 \mathrm{~kJ} \mathrm{~mol}{ }^{-1}\right)$ and pure metallic Pd $\left(60 \mathrm{~kJ} \mathrm{~mol}^{-1}\right)$ was consistent with the high atomic fraction of $\mathrm{Pd}$ in $\mathrm{Pd}_{0.8} \mathrm{Rh}_{0.2}$. The activation energy of $\mathrm{Pd}_{0.8} \mathrm{Rh}_{0.2}-\mathrm{H}_{2}-\mathrm{O}_{2}\left(66 \mathrm{~kJ} \mathrm{~mol}^{-1}\right)$ was slightly higher

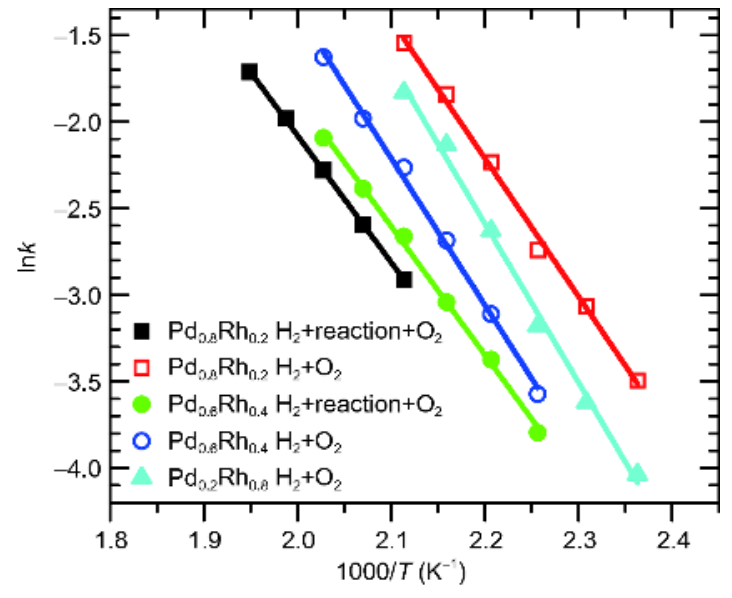

Figure 8 Arrhenius plots of Pd-Rh bimetallic catalysts for $\mathrm{CO}$ oxidation with varying compositions of $\mathrm{Pd} / \mathrm{Rh}$ and different pretreatments in the gaseous environment before $\mathrm{CO}$ oxidation.

than that of $\mathrm{Pd}_{0.8} \mathrm{Rh}_{0.2}-\mathrm{H}_{2}-\mathrm{CO}$ oxidation $-\mathrm{O}_{2}$ due to the diverse active phases. The activation energy for the sample

Table 2 Activation energies of Pd-Rh bimetallic catalysts for CO oxidation with a varied composition of Pd/Rh and experienced with different pretreatments in the gaseous environment before $\mathrm{CO}$ oxidation

\begin{tabular}{ccccc}
\hline Sample & Pretreatments & Activation energy $\left(\mathrm{kJ} \mathrm{mol}{ }^{-1}\right)$ & Temperature $\left({ }^{\circ} \mathrm{C}\right)$ & Active phase \\
\hline $\mathrm{Pd} \mathrm{NCs}$ & $\mathrm{H}_{2}$ pretreatment & 60 & $150-200$ & $\mathrm{Metallic} \mathrm{Pd}$ \\
$\mathrm{Pd}_{0.8} \mathrm{Rh}_{0.2} \mathrm{NCs}$ & $\mathrm{H}_{2}-$ reaction- $\mathrm{O}_{2}$ & 61 & $200-240$ & $\mathrm{Pd}_{0.75} \mathrm{Rh}_{0.25}$ alloy \\
$\mathrm{Pd}_{0.8} \mathrm{Rh}_{0.2} \mathrm{NCs}$ & $\mathrm{H}_{2}-\mathrm{O}_{2}$ pretreatment & 66 & $150-200$ & $\mathrm{Pd}_{0.67} \mathrm{Rh}_{0.33} / \mathrm{PdO}$ \\
$\mathrm{Pd}_{0.6} \mathrm{Rh}_{0.4} \mathrm{NCs}$ & $\mathrm{H}_{2}-$ reaction- $\mathrm{O}_{2}$ & 63 & $170-220$ & $\mathrm{RhO}_{x} / \mathrm{PdRh}$ \\
$\mathrm{Pd}_{0.6} \mathrm{Rh}_{0.4} \mathrm{NCs}$ & $\mathrm{H}_{2}-\mathrm{O}_{2}$ pretreatment & 69 & $170-220$ & $\mathrm{Pd}_{0.45} \mathrm{Rh}_{0.55}$ alloy \\
$\mathrm{Pd}_{0.2} \mathrm{Rh}_{0.8} \mathrm{NCs}$ & $\mathrm{H}_{2}-\mathrm{O}_{2}$ pretreatment & 76 & $150-220$ & $\mathrm{Pd}_{0.35} \mathrm{Rh}_{0.65}$ alloy \\
$\mathrm{Rh} \mathrm{NCs}$ & $\mathrm{H}_{2}$ pretreatment & 98 & $150-220$ & $\mathrm{Metallic} \mathrm{Rh}$
\end{tabular}


of $\mathrm{Pd}_{0.6} \mathrm{Rh}_{0.4}-\mathrm{H}_{2}-\mathrm{O}_{2}$ treatment was $69 \mathrm{~kJ} \mathrm{~mol}^{-1}$; the active phase of $\mathrm{Pd}_{0.6} \mathrm{Rh}_{0.4}-\mathrm{H}_{2}-\mathrm{O}_{2}$ tracked with AP-XPS was $\mathrm{Pd}_{0.45} \mathrm{Rh}_{0.55}$ bimetallic alloy (Fig $5 \mathrm{a} 7-5 \mathrm{a} 9$ and $5 \mathrm{~b} 7-5 \mathrm{~b} 9$ ). For $\mathrm{Pd}_{0.2} \mathrm{Rh}_{0.8}-\mathrm{H}_{2}-\mathrm{O}_{2}$, the activation barrier was $76 \mathrm{~kJ} \mathrm{~mol}^{-1}$; its surface phase was $\mathrm{Pd}_{0.35} \mathrm{Rh}_{0.65}$ bimetallic alloy (Fig. 7). Apparently, the activation energies of $\mathrm{Pd}_{x} \mathrm{Rh}_{1-x}$ bimetallic NCs increased in the order of the tracked active surfaces: $\mathrm{Pd}_{0.75} \mathrm{Rh}_{0.25}\left(61 \mathrm{~kJ} \mathrm{~mol}^{-1}\right)<\mathrm{Pd}_{0.45}$ $\mathrm{Rh}_{0.55}\left(69 \mathrm{~kJ} \mathrm{~mol}^{-1}\right)<\mathrm{Pd}_{0.35} \mathrm{Rh}_{0.65}\left(76 \mathrm{~kJ} \mathrm{~mol}^{-1}\right)$ (Table 2). Such observation was consistent with the conclusion reported in the literature where the activation barriers of $\mathrm{Pd}_{x} \mathrm{Rh}_{1-x} \mathrm{NPs}$ decreased with the increased atomic fraction of Pd [53]. On the other hand, the activation energy of the $\mathrm{Pd}_{0.6} \mathrm{Rh}_{0.4}-\mathrm{H}_{2}-\mathrm{CO}$ oxidation $-\mathrm{O}_{2}$ for $\mathrm{CO}$ oxidation was $63 \mathrm{~kJ} \mathrm{~mol}^{-1}$. AP-XPS studies of $\mathrm{Pd}_{0.6} \mathrm{Rh}_{0.4}-\mathrm{H}_{2}-\mathrm{CO}$ oxidation- $\mathrm{O}_{2}$ during $\mathrm{CO}$ oxidation uncovered that its active phase was $\mathrm{RhO}_{x}$ loaded on PdRh bimetallic alloy [53]. This was consistent with the reports where the active $\mathrm{RhO}_{x}$ was the active phase of Rh NPs with a size $\leqslant 2.5 \mathrm{~nm}$ $[48,55]$, in which the activation barrier of $\mathrm{RhO}_{x}$ was reported at ca. $68 \mathrm{~kJ} \mathrm{~mol}^{-1}$.

\section{CONCLUSIONS}

$\mathrm{Pd}_{x} \mathrm{Rh}_{1-x}$ NCs enclosed with (100) facets have been synthesized with high selectivity for the formation of bimetallic NC via a facile one-pot hydrothermal method with the aid of halide ions. By using $\mathrm{Pd}_{x} \mathrm{Rh}_{1-x}$ NCs with the same shape and similar size, we investigated the correlation between surface composition of these bimetallic NCs and their corresponding catalytic performances after varied pretreatments with the assistance of AP-XPS and kinetic analysis. In general, these in-situ studies of the three Pd-Rh bimetallic NCs revealed a strong dependence of surface chemistry on exposed atmospheres (e.g., $\mathrm{CO}$ $+\mathrm{O}_{2}, \mathrm{H}_{2}, \mathrm{O}_{2}$, etc.) and their overall compositions. Upon the pretreatments of $\mathrm{H}_{2}$ and $\mathrm{H}_{2}-\mathrm{O}_{2}$, bimetallic sites and metal/oxide interface could be created in $\mathrm{CO}$ oxidation at surface of $\mathrm{Pd}_{0.8} \mathrm{Rh}_{0.2} \mathrm{NCs}$ and $\mathrm{Pd}_{0.6} \mathrm{Rh}_{0.4} \mathrm{NCs}$, respectively, while only alloy sites were observed for $\mathrm{Pd}_{0.2} \mathrm{Rh}_{0.8} \mathrm{NCs}$ during the reaction. And surface segregation only took place during the $\mathrm{Pd}_{0.6} \mathrm{Rh}_{0.4}$ NCs-catalyzed CO oxidation, while surface compositions remained unchanged in the cases of $\mathrm{Pd}_{0.8} \mathrm{Rh}_{0.2} \mathrm{NCs}$ and $\mathrm{Pd}_{0.2} \mathrm{Rh}_{0.8} \mathrm{NCs}$. This study not only demonstrates the surface chemistry evolution of bimetallic catalysts during different pretreatments and catalysis, but also puts forward a post-synthesis method by atmosphere treatments to create bimetallic or metal/ oxide site for the reaction.

Received 10 March 2018; accepted 27 March 2018; published online 20 April 2018

1 Ertl G, Knoezinger H, Schueth F, Weitkamp J. Handbook of Heterogeneous Catalysis, 2nd Edition. Weinheim: Wiley-VCH, 2008

2 Bartholomew CH, Farrauto RJ. Fundamentals of Industrial Catalytic Processes, 2nd Edition. Weinheim: Wiley-AIChE, 2005

3 de Jong KP. Synthesis of Solid Catalysts, 1st Edition. Weinheim: Wiley-VCH, 2009

4 Somorjai GA, Li YM. Introduction to Surface Chemistry and Catalysis, 2nd Edition. Weinheim: Wiley, 2010

5 Roldan Cuenya B. Metal nanoparticle catalysts beginning to shapeup. Acc Chem Res, 2013, 46: 1682-1691

6 Somorjai GA. Modern surface science and surface technologies: an introduction. Chem Rev, 1996, 96: 1223-1236

7 Rodriguez JA. Physical and chemical properties of bimetallic surfaces. Surf Sci Rep, 1996, 24: 223-287

8 Mavrikakis M, Stoltze P, Nørskov JK. Making gold less noble. Catal Lett, 2000, 64: 101-106

9 Xu Z, Xiao FS, Purnell SK, et al. Size-dependent catalytic activity of supported metal clusters. Nature, 1994, 372: 346-348

10 Tian N, Zhou ZY, Sun SG, et al. Synthesis of tetrahexahedral platinum nanocrystals with high-index facets and high electrooxidation activity. Science, 2007, 316: 732-735

11 Bratlie KM, Lee H, Komvopoulos K, et al. Platinum nanoparticle shape effects on benzene hydrogenation selectivity. Nano Lett, 2007, 7: 3097-3101

12 Narayanan R, El-Sayed MA. Shape-dependent catalytic activity of platinum nanoparticles in colloidal solution. Nano Lett, 2004, 4: 1343-1348

13 Liu J, Fan X, Liu X, et al. Synthesis of cubic-shaped Pt particles with (100) preferential orientation by a quick, one-step and clean electrochemical method. ACS Appl Mater Interfaces, 2017, 9: 18856-18864

14 Ye KH, Wang Z, Li H, et al. A novel $\mathrm{CoOOH} /(\mathrm{Ti}, \mathrm{C})-\mathrm{Fe}_{2} \mathrm{O}_{3}$ nanorod photoanode for photoelectrochemical water splitting. Sci China Mater, 2018, 414

15 Zhang T, Liao SA, Dai LX, et al. Ir-Pd nanoalloys with enhanced surface-microstructure-sensitive catalytic activity for oxygen evolution reaction in acidic and alkaline media. Sci China Mater, 2018, 57

16 Chen JG, Menning CA, Zellner MB. Monolayer bimetallic surfaces: Experimental and theoretical studies of trends in electronic and chemical properties. Surf Sci Rep, 2008, 63: 201-254

17 Ferrando R, Jellinek J, Johnston RL. Nanoalloys: from theory to applications of alloy clusters and nanoparticles. Chem Rev, 2008, 108: 845-910

18 Boles MA, Ling D, Hyeon T, et al. The surface science of nanocrystals. Nat Mater, 2016, 15: 141-153

19 You H, Yang S, Ding B, et al. Synthesis of colloidal metal and metal alloy nanoparticles for electrochemical energy applications. Chem Soc Rev, 2013, 42: 2880-2904

20 Tao F, Grass ME, Zhang Y, et al. Reaction-driven restructuring of Rh-Pd and Pt-Pd core-shell nanoparticles. Science, 2008, 322: 932 934

21 Chaudhari RV, Jaganathan R, Kolhe DS, et al. Effect of catalyst pretreatment on activity and selectivity of hydrogenation of phenylacetylene over palladium/carbon catalyst. Ind Eng Chem Prod Res Dev, 1986, 25: 375-379

22 Krishnankutty N, Vannice MA. The effect of pretreatment on Pd/C 
catalysts: 2. Catalytic behavior. J Catal, 1995, 155: 327-335

23 Krishnankutty N, Vannice MA. The effect of pretreatment on Pd/C catalysts: 1. Adsorption and absorption properties. J Catal, 1995, 155: 312-326

24 Bauer JC, Mullins D, Li M, et al. Synthesis of silica supported $\mathrm{AuCu}$ nanoparticle catalysts and the effects of pretreatment conditions for the CO oxidation reaction. Phys Chem Chem Phys, 2011, 13: 2571-2581

25 Bar-Ziv R, Zidki T, Zilbermann I, et al. Effect of hydrogen pretreatment of platinum nanoparticles on their catalytic properties: reactions with alkyl radicals-a mechanistic study. ChemCatChem, 2016, 8: 2761-2764

26 Konsolakis M, Sgourakis M, Carabineiro SAC. Surface and redox properties of cobalt-ceria binary oxides: On the effect of Co content and pretreatment conditions. Appl Surf Sci, 2015, 341: 4854

27 Yang L, Kimmel YC, Lu Q, et al. Effect of pretreatment atmosphere on the particle size and oxygen reduction activity of low-loading platinum impregnated titanium carbide powder electrocatalysts. J Power Sources, 2015, 287: 196-202

28 Zhang S, Guo S, Zhu H, et al. Structure-induced enhancement in electrooxidation of trimetallic FePtAu nanoparticles. J Am Chem Soc, 2012, 134: 5060-5063

29 Kattel S, Ramírez PJ, Chen JG, et al. Active sites for $\mathrm{CO}_{2}$ hydrogenation to methanol on $\mathrm{Cu} / \mathrm{ZnO}$ catalysts. Science, 2017, 355: 1296-1299

30 Zhao G, Yang F, Chen Z, et al. Metal/oxide interfacial effects on the selective oxidation of primary alcohols. Nat Commun, 2017, 8: 14039

31 Du W, Yang G, Wong E, et al. Platinum-tin oxide core-shell catalysts for efficient electro-oxidation of ethanol. J Am Chem Soc, 2014, 136: 10862-10865

32 Ye Y, Wang L, Zhang S, et al. The role of copper in catalytic performance of a $\mathrm{Fe}-\mathrm{Cu}-\mathrm{Al}-\mathrm{O}$ catalyst for water gas shift reaction. Chem Commun, 2013, 49: 4385-4387

33 Zhang S, Shan J, Zhu Y, et al. WGS Catalysis and in situ studies of $\mathrm{CoO}_{1-x}, \mathrm{PtCo}_{n} / \mathrm{Co}_{3} \mathrm{O}_{4}$, and $\mathrm{Pt}_{m} \mathrm{Co}_{m} / \mathrm{CoO}_{1-x}$ nanorod catalysts. J Am Chem Soc, 2013, 135: 8283-8293

34 Wang $\mathrm{L}$, Zhang S, Zhu Y, et al. Catalysis and in situ studies of $\mathrm{Rh}_{1} /$ $\mathrm{Co}_{3} \mathrm{O}_{4}$ nanorods in reduction of $\mathrm{NO}$ with $\mathrm{H}_{2}$. ACS Catal, 2013, 3: 1011-1019

35 Shan J, Zhu Y, Zhang S, et al. Catalytic performance and in situ surface chemistry of pure $\alpha-\mathrm{MnO}_{2}$ nanorods in selective reduction of $\mathrm{NO}$ and $\mathrm{N}_{2} \mathrm{O}$ with CO. J Phys Chem C, 2013, 117: 8329-8335

36 Zhang $\mathrm{S}$, Shan J, Zhu Y, et al. Restructuring transition metal oxide nanorods for $100 \%$ selectivity in reduction of nitric oxide with carbon monoxide. Nano Lett, 2013, 13: 3310-3314

37 Tao FF. Operando studies of catalyst surfaces during catalysis and under reaction conditions: ambient pressure X-ray photoelectron spectroscopy with a flow-cell reactor. ChemCatChem, 2012, 4: 583-590

38 Zhu Y, Zhang S, Shan J, et al. In situ surface chemistries and catalytic performances of ceria doped with palladium, platinum, and rhodium in methane partial oxidation for the production of syngas. ACS Catal, 2013, 3: 2627-2639

39 Tao FF. Design of an in-house ambient pressure AP-XPS using a bench-top X-ray source and the surface chemistry of ceria under reaction conditions. Chem Commun, 2012, 48: 3812-3814

40 Wang SB, Zhu W, Ke J, et al. Pd-Rh nanocrystals with tunable morphologies and compositions as efficient catalysts toward Su- zuki cross-coupling reactions. ACS Catal, 2014, 4: 2298-2306

41 Zhu W, Ke J, Wang SB, et al. Shaping single-crystalline trimetallic Pt-Pd-Rh nanocrystals toward high-efficiency C-C splitting of ethanol in conversion to $\mathrm{CO}_{2}$. ACS Catal, 2015, 5: 1995-2008

42 Yin AX, Min XQ, Zhang YW, et al. Shape-selective synthesis and facet-dependent enhanced electrocatalytic activity and durability of monodisperse Sub-10 nm Pt-Pd tetrahedrons and cubes. J Am Chem Soc, 2011, 133: 3816-3819

43 Rainer DR, Wu M, Mahon DI, et al. Adsorption of $\mathrm{CO}$ on $\mathrm{Pd} /$ $\mathrm{Al}_{2} \mathrm{O}_{3} / \mathrm{Ta}(110)$ model catalysts. J Vacuum Sci Tech A-Vacuum Surfs Films, 1996, 14: 1184-1188

44 Goodman DW. Model studies in catalysis using surface science probes. Chem Rev, 1995, 95: 523-536

45 Teschner D, Pestryakov A, Kleimenov E, et al. High-pressure X-ray photoelectron spectroscopy of palladium model hydrogenation catalysts.Part 1: Effect of gas ambient and temperature. J Catal, 2005, 230: 186-194

46 Bennett PA, Fuggle JC. Electronic structure and surface kinetics of palladium hydride studied with X-ray photoelectron spectroscopy and electron-energy-loss spectroscopy. Phys Rev B, 1982, 26: 60306039

47 Cappillino PJ, Sugar JD, Hekmaty MA, et al. Nanoporous Pd alloys with compositionally tunable hydrogen storage properties prepared by nanoparticle consolidation. J Mater Chem, 2012, 22: 14013-14022

48 Grass ME, Zhang Y, Butcher DR, et al. A reactive oxide overlayer on rhodium nanoparticles during $\mathrm{CO}$ oxidation and its size dependence studied by in situ ambient-pressure X-ray photoelectron spectroscopy. Angew Chem Int Ed, 2008, 47: 8893-8896

49 Brun M, Berthet A, Bertolini JC. XPS, AES and auger parameter of Pd and PdO. J Electron Spectr Related Phenomena, 1999, 104: 5560

50 Gabasch H, Unterberger W, Hayek K, et al. In situ XPS study of Pd (111) oxidation at elevated pressure, Part 2: Palladium oxidation in the $10^{-1}$ mbar range. Surf Sci, 2006, 600: 2980-2989

51 Toyoshima R, Yoshida M, Monya Y, et al. In situ ambient pressure XPS study of CO oxidation reaction on Pd(111) surfaces. J Phys Chem C, 2012, 116: 18691-18697

52 Choi K. CO oxidation over Pd and Cu catalysts III. Reduced $\mathrm{Al}_{2} \mathrm{O}_{3}$ supported Pd. J Catal, 1991, 131: 1-21

53 Renzas JR, Huang W, Zhang $\mathrm{Y}$, et al. $\mathrm{Rh}_{1-\mathrm{x}} \mathrm{Pd}_{\mathrm{x}}$ nanoparticle composition dependence in $\mathrm{CO}$ oxidation by oxygen: catalytic activity enhancement in bimetallic systems. Phys Chem Chem Phys, 2011, 13: $2556-2562$

54 Oh S. Influence of metal particle size and support on the catalytic properties of supported rhodium: $\mathrm{CO}-\mathrm{O}_{2}$ and $\mathrm{CO}-\mathrm{NO}$ reactions. J Catal, 1991, 128: 526-536

55 Ligthart DAJM, van Santen RA, Hensen EJM. Supported rhodium oxide nanoparticles as highly active CO oxidation catalysts. Angew Chem Int Ed, 2011, 50: 5306-5310

Acknowledgements This work was supported by the National Natural Science Foundation of China $(21573005,21771009$, and 21621061), the National Key Research and Development Program of MOST of China (2016YFB0701100), and Beijing Natural Science Foundation (2162019). Financial aids from the US National Science Foundation (NSF MCB0824837), and the Georgia Cancer Coalition (GCC) Distinguished Cancer Clinicians and Scientists are also appreciated.

Author contributions Tao F and Zhang $\mathrm{Y}$ designed and guided the 
whole project; Zhu W synthesized the PdRh samples and conducted the structural characterizations; Shan J performed the AP-XPS and CO oxidation evaluations with the help of Nguyen L, Zhang S, Tao F, and Zhu W; Zhu W and Shan J wrote the paper with support from Tao F and Zhang YW. All authors contributed to the general discussion.
Conflict of interest The authors declare that they have no conflict of interest.

Supplementary information Supporting data are available in the online version of the paper.

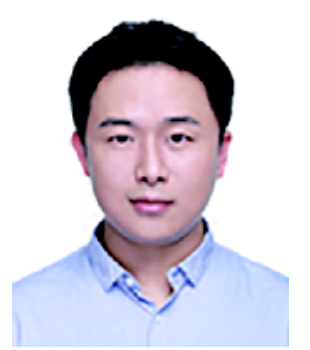

Wei Zhu received his BSc degree from the Department of Chemistry, Zhejiang University (2009), and his PhD degree from the College of Chemistry and Molecular Engineering, Peking University (2014), guided by Prof. Yawen Zhang and Prof. Chunhua Yan. He participated in an exchange program in Prof. Franklin Tao's group at University of Notre Dame (2012). Currently, he is working as a postdoc with Prof. Yadong Li and Prof. Chen Chen at the Department of Chemistry, Tsinghua University.

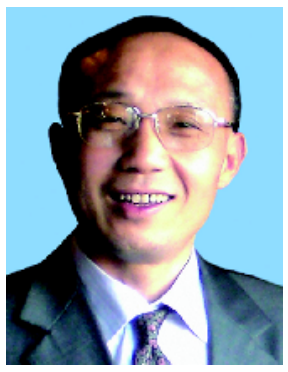

Ya-Wen Zhang is currently a professor and principle investigator at the College of Chemistry and Molecular Engineering, Peking University. His research interest lies in the rational design, controllable synthesis, ordered assembly, catalytic properties and structure-function relationships of rare earth \& noble metal nanostructures. He has published more than 130 papers in peer-reviewed scientific journals with a total citation times over 10,000.

\title{
PdRh双金属纳米立方体表面化学原位研究与CO氧化反应催化性能的关联
}

\author{
朱威 ${ }^{1,2}$, 单军军 ${ }^{2}$, Luan Nguyen ${ }^{2}, 弓$ 适然 $^{2}$, 陶丰 ${ }^{2^{*}}$, 张亚文 ${ }^{1^{*}}$
}

摘要 随着原位表征技术的进步, 最新的研究结果表明, 纳米催化剂在活化或催化反应条件下会发生表面结构或组分的变化, 进而影响其 催化性能. 而开展以具有明确结构和组分纳米晶为模型催化剂的原位催化反应研究, 对深入理解催化剂在反应中的活性中心状态和构效 关系能起到重要推进作用. 本研究利用水热法制备了具有一系列组成、相似尺寸及相同形貌的PdRh双金属纳米立方体, 针对CO催化氧化 反应, 结合原位X射线光电子能谱技术, 研究了不同预处理条件下和不同组成的纳米晶表面化学演化历程. 研究发现 $\mathrm{Pd}_{0.6} \mathrm{Rh}_{0.4}$ 和 $\mathrm{Pd}_{0.8} \mathrm{Rh}_{0.2}$ 两 种组分的纳米晶催化反应活性中心取决于其预活化条件, 而 $\mathrm{PdRh}$ 体系的元素偏析现象仅在 $\mathrm{Pd}_{0.6} \mathrm{Rh}_{0.4}$ 一种条件下发生. 因此, 本研究进一步 明晰了双金属催化剂表面结构在反应条件下的演变与催化性能的关联. 